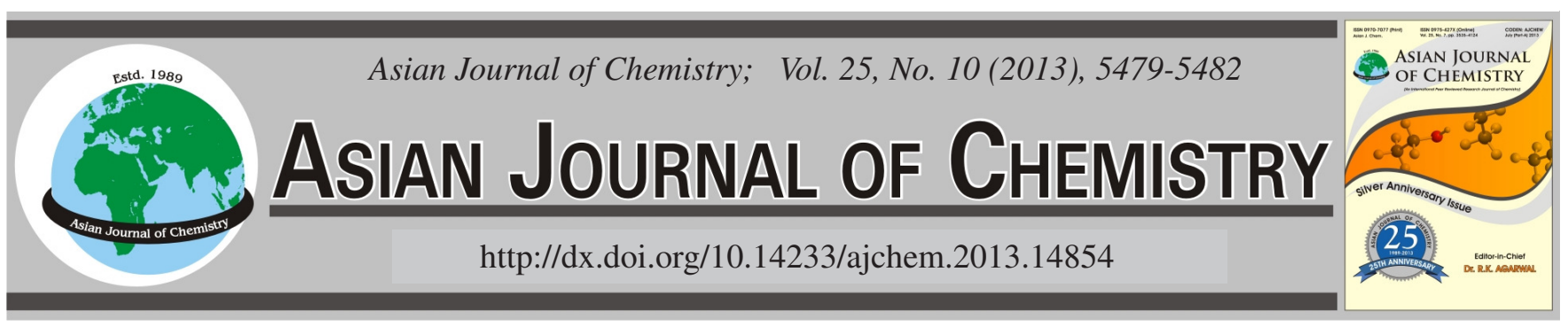

\title{
Chemical Analysis, Cytotoxicity and Antimicrobial Studies by Snapdragon: A Medicinal Plant
}

\author{
Muhammad Riaz ${ }^{1, *}$, Nasir Rasool ${ }^{1, *}$, Shahid Rasool ${ }^{2}$, Umer RAShid $^{3, *}$, IftikHar Hussain Bukhari ${ }^{1}$, \\ Muhammad Zubair ${ }^{1}$, Mnaza Noreen ${ }^{1}$ and Mazhar Abbas ${ }^{4}$
}

\begin{abstract}
${ }^{1}$ Department of Chemistry, Government College University Faisalabad-38000, Pakistan
${ }^{2}$ Faculty of Pharmacy, University of Sargodha, Sargodha-40100, Pakistan

${ }^{3}$ Institute of Advanced Technology, Universiti Putra Malaysia, 43400 UPM Serdang, Selangor, Malaysia

${ }^{4}$ Department of Chemistry and Biochemistry, University of Agriculture, Faisalabad-38040, Pakistan
\end{abstract}

*Corresponding authors: E-mail: nasirhej@yahoo.co.uk, riaz_453@yahoo.com, umer.rashid@yahoo.com

(Received: 21 November 2012;

Accepted: 13 April 2013)

AJC-13235

\begin{abstract}
In this work, we evaluated the antimicrobial, cytotoxicity properties of the snapdragon (Antirrhinum majus) extract and fractions. The cytotoxicity, studied by haemolytic activity against human blood erythrocytes assays, indicated a low cytotoxic effect on the absolute methanol extract and its fractions from plant. Chemical analysis of whole plant was also carried out. For chemical analysis HP-LC analysis was carried out to determine the presence of phenolics. The GC-MS analysis was also carried out to determine the presence of some phytoconstituents in $n$-hexane extract (extracted by soxhlet). The results of present study revealed that snapdragon plant might be considered as a good source of natural antimicrobial.
\end{abstract}

Key Words: Snapdragon, Antimicrobial activity, Cytotoxicity, GC-MS, HPLC.

\section{INTRODUCTION}

Medicinal plants represent a rich source of antimicrobial agents. Plants used medicinally in different countries were sources of many potent and powerful drugs. Although hundreds of plant species have been tested for antimicrobial properties, the vast majority of them have not been adequately evaluated $^{1-3}$. In developing countries where the environment, particularly public places, are not fully hygienic and even in highly developed countries, microorganisms such as bacteria causes many diseases ${ }^{4}$.

The plant extracts with a pleasant smell combined with a preservative action, have properties to avoid lipid deterioration and spoilage by microorganisms. The use of natural sources as functional ingredients in foods, drinks and cosmetics is gaining greater recognition, as the synthetic additives are potentially harmful 5 .

According to our knowledge no literature is available on the cytotoxicity, antimicrobial activity of the extract and various fractions of Snapdragon (Antirrhinum majus) belonging to Scrophulariaceae family. Therefore, this work investigates the antimicrobial and cytotoxicity (by haemolytic activity) of absolute methanol extract and its fractions from the whole plant of Snapdragon. The identification of bioactive constituents by HP-LC and GC-MS was also carried out from the whole plant of Snapdragon.

\section{EXPERIMENTAL}

The whole plant was collected from local areas of Faisalabad, Pakistan. The plant was identified by Mansoor Hameed, Assistant Professor, Department of Botany, University of Agriculture, Faisalabad. The voucher specimen (4425) has been deposited in Herbarium/collection University of Agriculture Faisalabad. After collection, the plant material was washed, shade dried and grinded. The whole plant $(5 \mathrm{Kg})$ was extracted thrice with absolute methanol $(3 \times 7 \mathrm{~L})$ by dipping for 7 days each time. The extracts were mixed and concentrated to dryness using rotary evaporator. The absolute methanol extract was further fractioned by using solvents of increasing polarity: chloroform, ethyl acetate and $n$-butanol. After fractionation, samples were concentrated to dryness and stored in a refrigerator at $4{ }^{\circ} \mathrm{C}$, until used for analysis.

Antimicrobial activity: In order to evaluate the antimicrobial activity of selected bacterial strains such as Pasturella multocida, Escherichia coli, Bacillus subtilis and Staphylococcus aureus and fungal strains Aspergillus niger, Aspergillus flavus, Alternaria alternata and Rhizopus solani by using plant extract and fractions analyzed by disc diffusion method as earlier described ${ }^{6}$ at different concentrations. For ciprofloxacin and fungone were used for bacterial and fungal strains as a standard. 
TABLE-1

ANTIMICROBIAL ACTIVITY IN TERMS OF INHIBITION ZONE BY SNAPDRAGON PLANT AGAINST SELECTED BACTERIAL AND FUNGAL STRAINS AT A CONCENTRATION OF $1 \mathrm{mg} / \mathrm{mL}$

\begin{tabular}{|c|c|c|c|c|c|c|c|c|}
\hline \multicolumn{9}{|c|}{ Inhibition zones (mm) by disc diffusion assay } \\
\hline \multirow[t]{2}{*}{ Extract and fractions } & \multicolumn{4}{|c|}{ Bacterial strains } & \multicolumn{4}{|c|}{ Fungal strains } \\
\hline & E. coli & P. multocida & S. aureus & B. subtilis & A. flavus & A. alternata & R. solani & A. niger \\
\hline Absolute methanol & $10.24 \pm 0.10$ & $12.41 \pm 0.12$ & $14.40 \pm 0.13$ & $11.20 \pm .09$ & $9.20 \pm 0.07$ & $10.16 \pm 0.10$ & $11.00 \pm 0.10$ & $12.30 \pm 0.12$ \\
\hline$n$-Butanol & N.D. & N.D. & N.D. & $8.20 \pm 0.07$ & N.D. & N.D. & N.D. & N.D. \\
\hline Chloroform & N.D. & $8.01 \pm 0.07$ & N.D. & N.D. & N.D. & N.D. & $9.15 \pm 0.09$ & N.D. \\
\hline Ethyl acetate & $7.20 \pm 0.08$ & $11.12 \pm 0.11$ & $10.20 \pm 0.08$ & $11.24 \pm 0.10$ & $8.20 \pm 0.08$ & $9.36 \pm 0.11$ & $10.20 \pm 0.09$ & $10.40 \pm 0.09$ \\
\hline $\begin{array}{l}n \text {-Hexane extract (by } \\
\text { soxhlet) }\end{array}$ & N.D.* & N.D. & $7.40 \pm 0.05$ & N.D. & N.D. & $7.41 \pm 0.07$ & $6.80 \pm 0.07$ & N.D. \\
\hline$†$ Ciprofloxacin/fungone & $28.30 \pm 0.15$ & $27.20 \pm 0.21$ & $30.10 \pm 0.16$ & $29.20 \pm 0.15$ & $22.50 \pm 0.18$ & $24.60 \pm 0.23$ & $29.70 \pm 0.21$ & $28.10 \pm 0.26$ \\
\hline
\end{tabular}

TABLE-2

ANTIMICROBIAL ACTIVITY IN TERMS OF INHIBITION ZONE BY SNAPDRAGON PLANT AGAINST SELECTED BACTERIAL AND FUNGAL STRAINS AT A CONCENTRATION OF 3 mg/mL

\begin{tabular}{|c|c|c|c|c|c|c|c|c|}
\hline \multicolumn{9}{|c|}{ Inhibition zones (mm) by disc diffusion assay } \\
\hline \multirow[t]{2}{*}{ Extract and fractions } & \multicolumn{4}{|c|}{ Bacterial strains } & \multicolumn{4}{|c|}{ Fungal strains } \\
\hline & E. coli & P. multocida & S. aureus & B. subtilis & A. flavus & A. alternata & R. solani & A. niger \\
\hline Absolute methanol & $16.40 \pm 0.14$ & $18.32 \pm 0.14$ & $20.70 \pm 0.19$ & $15.20 \pm 0.14$ & $12.20 \pm 0.09$ & $14.36 \pm 0.11$ & $17.30 \pm 0.12$ & $16.30 \pm 0.13$ \\
\hline$n$-Butanol & N.D. * & $9.21 \pm 0.07$ & N.D. & $13.20 \pm 0.13$ & $8.80 \pm 0.06$ & $8.87 \pm 0.07$ & N.D. & $8.60 \pm 0.07$ \\
\hline Chloroform & $14.10 \pm 0.12$ & $10.26 \pm 0.09$ & N.D. & N.D. & $9.70 \pm 0.07$ & N.D. & $11.15 \pm 0.13$ & N.D. \\
\hline Ethyl acetate & $15.20 \pm 0.11$ & $13.23 \pm 0.13$ & $15.40 \pm 0.13$ & $14.30 \pm 0.12$ & $11.50 \pm 0.10$ & $11.36 \pm 0.12$ & $12.23 \pm 0.09$ & $11.40 \pm 0.06$ \\
\hline $\begin{array}{l}n \text {-Hexane extract } \\
\text { (extracted by soxhlet) }\end{array}$ & $12.20 \pm 0.12$ & N.D. & $9.15 \pm 0.10$ & $8.20 \pm 0.07$ & N.D. & $8.20 \pm 0.07$ & $9.40 \pm 0.07$ & $8.80 \pm 0.05$ \\
\hline Ciprofloxacin/Fungone & $28.30 \pm 0.15$ & $27.20 \pm 0.21$ & $30.10 \pm 0.16$ & $29.20 \pm 0.15$ & $22.50 \pm 0.18$ & $24.60 \pm 0.23$ & $29.70 \pm 0.21$ & $28.10 \pm 0.26$ \\
\hline
\end{tabular}

Cytotoxicity studies by haemolytic activity: Cytotoxicity studies of the plant extract and its fractions were analyzed by haemolytic activity using the reported method ${ }^{7,8}$ with some modifications.

GC-MS analysis of $\boldsymbol{n}$-hexane extract (extracted by soxhlet): The dried and ground plant whole plant $50 \mathrm{~g}$ was extracted with $n$-hexane through soxhlet for GC-MS analysis at $69^{\circ} \mathrm{C}$ for $4 \mathrm{~h}$. The sample was analyzed using GC-MS (QP2010 SHIMADZU, Japan). GC was equipped with capillary column (DB-5) as earlier described methods ${ }^{9,10}$. Ions/fragments were monitored in scanning mode through $40-550 \mathrm{~m} / \mathrm{z}$. The identification of the components was based on comparison of their retention index $(\mathrm{RI})$, relative to a standard alkanes series $\left(\mathrm{C}_{9^{-}}\right.$ $\mathrm{C}_{24}$ ). The compounds were further indentified and authenticated using their MS data by comparison with those of the NIST 05 mass spectral library and published mass spectra ${ }^{11,12}$.

HPLC analysis: For the preparation of sample to inject in HPLC the whole plant was extracted following the already reported method by ${ }^{13}$. The analysis of phenolics was performed using a high performance liquid chromatography. An HPLC (model LC-10A, Shimadzu, Japan) equipped with two LC-10 AS pumps, SCL-10A system control unit, Rheodyne injector, CTO-10A column oven, SPD-10A UV-VIS detector and data acquisition class CSW32 software was used. The $20 \mu \mathrm{L}$ volume of the filtered sample was injected into an analytical column (Shim-Pak CLC-ODS, $250 \times 4.6 \mathrm{~mm} ; 5 \mu \mathrm{m}$ particle size). The detection was carried out at $280 \mathrm{~nm}$. The identification was made by external standard methods by comparing with the known standard used on same conditions.
Statistical analysis: All the experiments were performed in triplicate and statistical analysis of the data was carried out by analysis of variance, using CoStat 6.3 software. A probability value of difference $p \leq 0.05$ was considered to denote a statistical significance. All data were presented as the mean values \pm standard deviation $(\mathrm{SD})$.

\section{RESULTS AND DISCUSSION}

Antimicrobial activity: The antimicrobial assay of the samples against selected microorganisms was appraised at different concentrations of plant extract and fractions (Tables 1-3). The results showed that when the concentration of plant extract and fraction was increased the antimicrobial activity also increased. The plant samples exhibited considerable antimicrobial activity against most of the bacterial and fungal strains. Disc diffusion method measured in inhibition zone (IZ) indicated that absolute methanol extract has significant inhibitory activity at the concentration of $10 \mathrm{mg} / \mathrm{mL}$ against bacterial strains such as $S$. aureus $(\mathrm{IZ}=33.60 \mathrm{~mm})$, B. subtilis $(\mathrm{IZ} 31.40 \mathrm{~mm})$, P. multocida (IZ $29.40 \mathrm{~mm}$ ), E. coli (IZ $30.50 \mathrm{~mm}$ ) and against fungal strains $R$. solani, (IZ31.10 mm), A. niger (IZ30.30 mm), A. alternata (IZ $27.20 \mathrm{~mm}$ ) and A. flavus (IZ 25.30) respectively. The $n$-hexane extract (extracted by soxhlet) showed less activity against all the tested bacterial and fungal strains. It was observed that when the concentration of plant extract and fraction increased to $5 \mathrm{mg} / \mathrm{mL}$ some of the strains also inhibited which were resistant at $1 \mathrm{mg} / \mathrm{mL}$ concentration.

The $n$-butanol fraction was unable to inhibit the growth of $E$. coli. The chloroform fraction was also unable to inhibit 
TABLE-3

ANTIMICROBIAL ACTIVITY IN TERMS OF INHIBITION ZONE BY SNAPDRAGON PLANT AGAINST SELECTED BACTERIAL AND FUNGAL STRAINS AT A CONCENTRATION OF $5 \mathrm{mg} / \mathrm{mL}$

\begin{tabular}{|c|c|c|c|c|c|c|c|c|}
\hline \multicolumn{9}{|c|}{ Inhibition zones (mm) by disc diffusion assay } \\
\hline \multirow{2}{*}{ Extract and fractions } & \multicolumn{4}{|c|}{ Bacterial strains } & \multicolumn{4}{|c|}{ Fungal strains } \\
\hline & E. coli & P. multocida & S. aureus & B. subtilis & A. flavus & A. alternata & R. solani & A. niger \\
\hline Methanol & $30.50 \pm 0.21$ & $29.40 \pm 0.32$ & $33.60 \pm 0.3$ & $31.40 \pm 0.30$ & $25.30 \pm 0.19$ & $27.20 \pm 0.21$ & $31.10 \pm 0.32$ & $30.30 \pm 0.23$ \\
\hline$n$-Butanol & N.D.* & $18.10 \pm 0.17$ & $17.20 \pm 0.21$ & $28.20 \pm 0.07$ & $18.70 \pm 0.06$ & $22.60 \pm 0.07$ & $16.20 \pm 0.11$ & $23.10 \pm 0.07$ \\
\hline Chloroform & $28.40 \pm 0.28$ & $20.26 \pm 0.19$ & N.D. & N.D. & $20.70 \pm 0.05$ & N.D. & $22.15 \pm 0.13$ & N.D. \\
\hline Ethyl acetate & $29.20 \pm 0.24$ & $28.23 \pm 0.11$ & $31.40 \pm 0.09$ & $30.30 \pm 0.09$ & $24.10 \pm 0.11$ & $25.36 \pm 0.12$ & $30.20 \pm 0.09$ & $29.40 \pm 0.06$ \\
\hline $\begin{array}{l}n \text {-Hexane extract } \\
\text { (extracted by Soxhlet) }\end{array}$ & $25.20 \pm 0.17$ & $17.20 \pm 0.10$ & $26.20 \pm 0.11$ & $24.22 \pm 0.06$ & $16.20 \pm 0.11$ & $19.41 \pm 0.07$ & $22.42 \pm 0.07$ & $17.83 \pm 0.05$ \\
\hline Ciprofloxacin/fungone & $28.30 \pm 0.15$ & $27.20 \pm 0.21$ & $30.10 \pm 0.16$ & $29.20 \pm 0.15$ & $22.50 \pm 0.18$ & $24.60 \pm 0.23$ & $29.70 \pm 0.21$ & $28.10 \pm 0.26$ \\
\hline
\end{tabular}

the growth of S. aureus, B. subtilis, A. alternata and A. niger. The ethyl acetate fraction showed significant activity as compared to the other fractions (Table-3). Ciprofloxacin and fungone were used as positive control for bacterial and fungal strains respectively. The activity of plant extract and fraction was greater from the standard drugs when the concentration increased up to $5 \mathrm{mg} / \mathrm{mL}$. It previous studies reported that the extracts tested were active against the fungus strains ${ }^{14-16}$ and their findings are somewhat comparable with our results.

So the Snapdragon plant extract and fractions may be used for the inhibition of bacteria and fungi.

Cytotoxicity studies by haemolytic activity: The cytotoxicity studies of the plant extract and its fractions by haemolytic activity was assayed against human red blood cells (RBCs) using Triton X-100 as positive control (99.78). The percentage lysis was evaluated by comparing the absorbance of sample with the Triton X-100 as positive control. The percentage lysis of red blood cells was calculated as described in the method section. Fig. 1 showed the percent lysis red blood cells was observed after treatment with Snapdragon absolute methanol extract and its fractions as follows: absolute methanol extract (4.89 \pm 0.04$), n$-butanol $(4.14 \pm 0.05)$, chloroform (3.18 $\pm 0.02)$, ethyl acetate $(2.23 \pm 0.03)$ and $n$-hexane extract (extracted by soxhlet) $(2.45 \pm 0.02)$. The stability of the red blood cells membrane is a good in vitro indicator of the cytotoxicity of administered substances. In our study, the percent lysis of human erythrocytes resulted in less than $5.0 \%$ for all samples, thus these findings indicate minor cytotoxicity of the tested samples which was also comparable with earlier findings $s^{7,17}$.

HPLC analysis: The whole plant was also analyzed for its polar constituents such as phenolics by HPLC technique (Table-4). The maximum amount of phenolics $(\mu \mathrm{g} / \mathrm{g})$ was evaluated in plant i.e. ferulic acid $(3.43 \pm 0.02), p$-coumaric

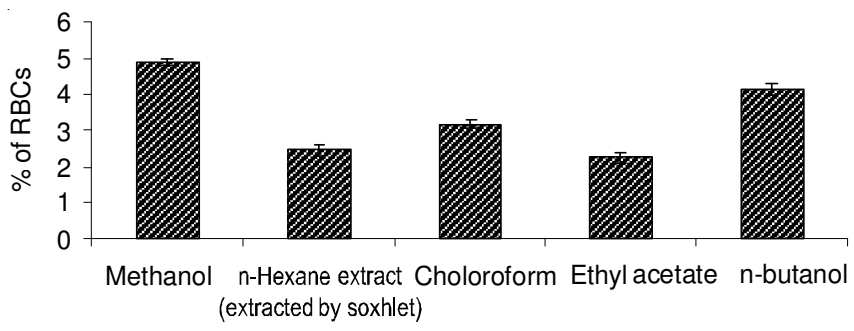

Fig. 1. \% lysis of red blood cells by the plant extract and fractions acid $(0.89 \pm 0.04)$, syringic acid $(6.96 \pm 0.06)$, chlorogenic acid $(2.82 \pm 0.03)$. Some chemical constituents were not identified. Therefore, the phenolics found in Snapdragon may play a vital role in the antimicrobial activities. The data presented in Table- 4 were the mean of three independent experiments. However, from the literature it observed that phytochemicals such as phenolic acids had the phenolic moiety which was known as a strong biological property ${ }^{18}$.

\begin{tabular}{|c|c|c|c|}
\hline \multicolumn{4}{|c|}{$\begin{array}{l}\text { TABLE-4 } \\
\text { AMOUNT OF CHEMICAL COMPOUNDS ANALYZED } \\
\text { BY HPLC IN SNAPDRAGON }\end{array}$} \\
\hline $\begin{array}{c}\text { Ferulic acid } \\
(\mu \mathrm{g} / \mathrm{g})\end{array}$ & $\begin{array}{c}\text { Syringic acid } \\
(\mu \mathrm{g} / \mathrm{g})\end{array}$ & $\begin{array}{c}\text { Chlorogenic } \\
\text { acid }(\mu \mathrm{g} / \mathrm{g})\end{array}$ & $\begin{array}{c}p \text {-Coumaric } \\
\text { acid }(\mu \mathrm{g} / \mathrm{g})\end{array}$ \\
\hline $3.43 \pm 0.02$ & $6.96 \pm 0.05$ & $2.82 \pm 0.03$ & $0.89 \pm 0.06$ \\
\hline
\end{tabular}

GC-MS analysis of $\boldsymbol{n}$-hexane extract (extracted by soxhlet): The less polar chemical compounds identified by GC-MS analysis of $n$-hexane extract (extracted by using soxhlet) were presented in Table-5. The major compounds determined in the $n$-hexane extract were: hexadecanioc acid methyl ester (59.99\%), octadecanioc acid ethyl ester $(13.57 \%)$, carvomenthone $(5.44 \%)$ respectively. Some of the compounds were present in traces and not indentified in less concentration as compared to other indentified compounds. The $n$-hexane extract may have some phytoconstituents which may be implicated in some biological activities such as antimicrobial activity. During earlier reports it was found that some phyto-components, methyl ester showed biological activities $^{10}$

The basis of varying degree of biological activities of $n$-hexane extract may be due to the nature and combinations of some constituents present in the $n$-hexane extract ${ }^{19}$. The synergistic or antagonistic activity between some components may affect the observed antimicrobial activity of the samples ${ }^{20}$.

\section{Conclusion}

Snapdragon whole plant showed good antimicrobial activity. The haemolytic activity of plant against human blood erythrocytes (RBCs) revealed a minor cytotoxicity as compared to the positive control. In conclusion, Snapdragon whole plant can be considered a good source of natural antimicrobial source. 


\begin{tabular}{clc}
\hline \multicolumn{3}{c}{ TABLE-5 } \\
\multicolumn{3}{c}{ CHEMICAL CONSTITUENTS IDENTIFIED IN THE OF $n$ - } \\
HEXANE EXTRACT OF SNAPDRAGON BY GC-MS ANALYSIS \\
\hline Retention index & Name of compounds & Area (\%) \\
\hline 816 & 1-Methoxybutane & 0.92 \\
952 & 3-Methylcyclohexanone & 2.90 \\
985 & 4-Methylnonane & 2.60 \\
1063 & 3,8-Dimethylundecane & 1.71 \\
1068 & (E,E)-3,5-Octadien-2-one & 1.40 \\
1099 & Hexadecane & 0.88 \\
1113 & trans-p-Mentha-2,8-dien-1-ol & 1.17 \\
1129 & 2-Ethyl hexanoic acid & 2.14 \\
1181 & Carvomenthone & 5.44 \\
1182 & trans-1,3, cis-1,4-Menthol & 1.66 \\
1259 & 4-Methyldecane & 0.74 \\
1282 & 6-Isopropyl-3-methylcyclohexen-2-one & 0.60 \\
1494 & Ethyl undecanoate & 1.53 \\
2000 & Eicosane & 1.92 \\
2102 & Octadecanioc acid ethyl ester & 13.57 \\
2934 & Hexadecanioc acid methyl ester & 59.99 \\
N.I.* & Protoverine & $\mathrm{t}^{*}$ \\
N.I. & Not identified & 0.46 \\
\hline * $\mathrm{t}$ traces; N.I.* & Not Identified. &
\end{tabular}

\section{ACKNOWLEDGEMENTS}

The financial support by Higher Education Commission (HEC), Islamabad, Pakistan, for providing scholarship to Muhammad Riaz by indigenous scholarship scheme for purchase chemicals and other research material is gratefully acknowledged.

\section{REFERENCES}

1. M.A. Hanif, A.Y. Al-Maskri, Z.M.H. Al-Mahruqi, J.N. Al-Sabahi, A Al-Azkawi and M.Y. Al-Maskari, Nat. Prod. Commun., 6, 1451 (2011).
2. B. Mahesh and S. Satish, World J. Agric. Sci., 4, 839 (2008).

3. Sobia, M. Zubair, N. Rasool, F. Anjum, M. Iqbal, M. Mushtaq and M. Shahid, J. Med. Plants Res., 7, 243 (2013).

4. S.A.R. Naqvi, M.M. Ishfaq, Z.A. Khan, S.A. Nagra, I.H. Bukhari, A.I. Hussain, N. Mahmood, S.A. Shahzad, A. Haque and T.H. Bokhari, Turk. J. Chem., 36, 267 (2012).

5. D.W. Reische, D.A. Lillard and R.R. Eitenmiller, Antioxidants in food lipids, Marcel Dekker, New York, USA, edn. 1, pp. 423-448 (1998).

6. CLSI, Clinical and Laboratory Standards Institute Performance Standards for Antimicrobial Susceptibility Testing, Clinical and Laboratory Standards Institute, Wayne, PA, USA, edn. 18, pp. 1-50 (2008).

7. W.A. Powell, C.M. Catranis and C.A. Maynard, Lett. Appl. Microbiol., 31, 163 (2000).

8. P. Sharma and J.D. Sharma, J. Ethnopharmacol., 74, 239 (2001).

9. E. Nazifi, A. Delazar, A. Movafeghi, Hemmati, H. Nazemiyeh, L. Nahar and S.D. Sarker, Record Nat. Prod., 2, 94 (2008).

10. A.T. Orishadipe, J.I. Okogun and E. Mishelia, Afr. J. Pure and App. Chem., 4, 131 (2010).

11. R.P. Adams, Identification of Essential Oil Components by Gas Chromatography/Mass Spectroscopy, Allured Publishing Corporation, Carol Stream IL, United States of America, edn. 3, pp. 1-804 (2001).

12. F. Aslam, N. Rasool, M. Riaz, M. Zubair, K. Rizwan, M. Abbas, T.H. Bukhari and I.H. Bukhari, Int. J. Phytomed., 3, 567 (2011).

13. S. Demiray, M.E. Pintado and P.M.L. Castro, World Acad. Sci. Eng. Technol., 54, 312 (2009).

14. A.A. Hamid and O.O. Aiyelaagbe, Int. J. Chem. Biochem. Sci., 1, 99 (2012).

15. M. Riaz, N. Rasool, I. Bukhari, M. Shahid, F. Zahoor, M. Gilani and M. Zubair, Afr. J. Microbiol. Res., 6, 5700 (2012).

16. A. Verastegui, J. Verde, S. Garcia, N. Heredia, A. Oranday and C. Rivas, World J. Microbiol. Biotechnol., 24, 1249 (2008).

17. M. Riaz, N. Rasool, I.H. Bukhari, M. Shahid, M. Zubair, K. Rizwan and U. Rashid, Molecules, 17, 14275 (2012).

18. X.C. Weng and M.H. Gordon, J. Agric. Food Chem., 40, 1331 (2000).

19. M.T. Baratta, H.J.D. Dorman, S.G. Deans, D.M. Biondi and G. Ruberto, J. Essent. Oil Res., 10, 618 (1998).

20. A. Giweli, A.M. Dzamic, M. Sokovic, M.S. Ristic and P.D. Marin, Molecules, 17, 4836 (2012). 